\title{
Chemiluminescence study of carbonate and peroxynitrous acid and its application to the direct determination of nitrite based on solid surface enhancement
}

\author{
Chao Lu ${ }^{a}$, Jin-Ming Lin ${ }^{a}{ }^{a}$, Carmen W. Huie ${ }^{b}$, Masaaki Yamada ${ }^{c}$ \\ ${ }^{a}$ Research Center for Eco-Environmental Sciences, Chinese Academy of Sciences, P.O. Box 2871, Beijing 100085, China \\ ${ }^{\mathrm{b}}$ Department of Chemistry, Hong Kong Baptist University, Kowloon Tong, Hong Kong, China \\ ${ }^{\mathrm{c}}$ Department of Applied Chemistry, Graduate School of Engineering, Tokyo Metropolitan University, 1-1 Minami-Ohsawa, \\ Hachioji, Tokyo 192-0397, Japan
}

Received 25 July 2003; received in revised form 9 December 2003; accepted 18 December 2003

\begin{abstract}
Peroxynitrous acid $(\mathrm{ONOOH})$ was produced by the on-line mixing of acidified hydrogen peroxide with nitrite in a flow system. A strong chemiluminescent $(\mathrm{CL})$ emission was observed when $\mathrm{ONOOH}$ reacted with carbonate without any special CL reagents. When cotton was present in the CL cell, the CL emission was enhanced significantly. The method was developed to determine nitrite, which showed a key improvement that any CL reagents and sensitizers were not used, resulting in better selectivity. The applicability of the present CL system was demonstrated for the sensitive and selective determination of nitrite in natural water samples without any special pretreatment. Good agreements were obtained for the determination of nitrite in tap and well waters between the present approach and a standard spectrophotometric method. The average precision was $4.6 \%(n=7)$ and detection limit $(S / N=3)$ was $1.0 \times 10^{-7} \mathrm{M}$. Based on the CL spectrum, UV spectra, and dissolved oxygen measurement, a possible CL mechanism was proposed. ONOOH was an unstable compound in acidic solution and could be quenched into peroxynitrite $\left(\mathrm{ONOO}^{-}\right)$in basic solution. $\mathrm{ONOO}^{-}$reacted with $\mathrm{CO}_{2}$ to produce $\mathrm{ONOOCO}_{2}^{-}$, which can rapidly decompose into ${ }^{\bullet} \mathrm{NO}_{2}$ and ${ }^{\bullet} \mathrm{CO}_{3}{ }^{-}$radicals. In the presence of $\mathrm{H}^{+},{ }^{\bullet} \mathrm{CO}_{3}{ }^{-}$radicals can protonate to bicarbonate radical $\left(\mathrm{HCO}_{3}{ }^{\bullet}\right)$. The recombination of $\mathrm{HCO}_{3}{ }^{\bullet}$ radicals and decomposition can lead to light emission.
\end{abstract}

(C) 2004 Elsevier B.V. All rights reserved.

Keywords: Solid surface enhancement; Chemiluminescence; Peroxynitrous acid; Nitrite; Natural water

\section{Introduction}

The determination of nitrite concentration in water, atmosphere, food, and other materials is of great importance for environmental protection, food assurance and quality control because of its potential toxicity. For its measurement, many analytical methods have been reported, such as spectrophotometric [1], electrochemical [2], and fluorometric [3] methods. The commonly employed spectrophotometric methods based on the diazo coupling reaction require close control of $\mathrm{pH}$ and temperature during the diazotization step and a relatively long coupling time. The electrochemical detection

\footnotetext{
* Corresponding author. Tel.: +86-10-62841953; fax: +86-10-62841953.

E-mail address: jinming1998@yahoo.com (J.-M. Lin).
}

almost suffers from the complicated preparation process of the electrodes and low sensitivity. The fluorometry is often based on the reactions of nitrite with fluorescent dyes. However, the fluorescent dyes have potential strong background fluorescence resulting from the dissolved organic substances in real samples. Therefore, it is difficult to meet the requirement for the analysis of nitrite in real samples.

Chemiluminescene (CL) is known as a powerful analytical technique that promises high sensitivity, wide linear range and simple instrumentation and has been applied successfully to assay of nitrite. To the best of our knowledge, the majority of the CL assays for nitrite are based on the conversion of nitrite to nitric oxide, which is detected in the gas phase by the CL reaction with ozone [4,5]. However, phase transformation need strip nitric oxide from solution with an inert gas, resulting in tedious procedure and low sensitivity. 
Peroxynitrite $\left(\mathrm{ONOO}^{-}\right)$and its conjugate peroxynitrous acid $(\mathrm{ONOOH})$ are powerful oxidants, which are receiving intensive investigation as the potential pathogenic agents in human diseases [6-8]. Peroxynitrite was generated from peroxynitrous acid in $\mathrm{NaOH}$ solution, and peroxynitrous acid was produced as a result of the reaction of nitrite with acidified hydrogen peroxide [9]. Mikuska et al. [10] described the determination of nitrite, based on the CL reaction of peroxynitrous acid with alkaline luminol solution. Moreover, in our previous work [11], a flow-injection CL method for the determination of nitrite was reported due to the decomposition of peroxynitrite into $\mathrm{NO}^{-}$and singlet oxygen $\left({ }^{1} \mathrm{O}_{2}\right)$ (the proposed CL emitter) in the presence of a suitable surfactant (at concentration above its CMC) and a sensitizer. Unfortunately, the above two reports suffered from low selectivity due to the presence of luminol and surfactant/sensitizer, respectively, resulting in the serious interferences of many cations. Therefore, a cation-exchange column was used for eliminating the interferences of cations.

Solid surface (e.g. cotton, glass wool, and filter paper) enhancement chemiluminescence is an interesting phenomenon. However, the mechanism of the CL enhancement on solid surface is difficult to understood. For example, Yoshinaga et al. [12] demonstrated a solid surface might have some effect on the CL quantum yield or energy-transfer efficiencies. Moreover, Wampler and coworkers [13] postulated the geometry of the cell might be a factor in CL enhancement studies. Therefore, to the best of our knowledge, the reports on solid surface CL enhancement phenomenon for analyses were rather rare [14].

It is well known that peroxynitrite is capable of inducing luminol CL in the presence of carbonate. This is because that peroxynitrite can react with carbon dioxide to form the more reactive free radical species of $\mathrm{ONOOCO}_{2}{ }^{-}$and $\mathrm{HCO}_{3}{ }^{\bullet}$ radicals, which can react with luminol and form free luminol radical more rapidly $[15,16]$. Furthermore, Radi and coworkers [8] observed a spontaneous CL phenomenon during the interactions of peroxynitrite with carbon dioxide/bicarbonate, suggesting the formation of $\mathrm{HCO}_{3}{ }^{\bullet}$ radicals. In the present work, it was found that the replacement of $\mathrm{NaOH}$ by $\mathrm{Na}_{2} \mathrm{CO}_{3}$ from the on-line reaction of nitrite with acidified hydrogen peroxide gave a strong CL emission in the absence of any special CL reagents such as luminol and lucigenin. When cotton was present in the CL cell, the CL emission was enhanced significantly. These observations were developed for the determination of nitrite in tap and well waters without any pretreatment and the results were compared with a standard spectrophotometric method [17]. The proposed method was simpler and more selective than the above two reports using peroxynitrite system $[10,11]$ for the sensitive assays for nitrite. In addition, based on the CL spectrum, UV spectra and dissolved oxygen measurement, a reasonable CL mechanism from the reaction of peroxynitrous acid with carbonate was proposed. Also, the possible mechanism of the solid surface enhancement on CL was discussed in brief.

\section{Experimental}

\subsection{Reagents}

All reagents were of analytical grade and used without further purification. Water was obtained from Milli-Q purification system (Barnstead, CA, USA). A $0.1 \mathrm{M}$ nitrite solution was prepared by dissolving $0.69 \mathrm{~g} \mathrm{NaNO}_{2}$ (Beijing Chemical Reagent Company, Beijing, China), pre-dried at $110^{\circ} \mathrm{C}$ for $4 \mathrm{~h}$, in $100 \mathrm{ml}$ of water. A small amount of sodium hydroxide $(\mathrm{NaOH})$ was added to the above solution to prevent its decomposition and $1.0 \mathrm{ml}$ of chloroform to inhibit bacterial growth. The working solutions of nitrite were freshly prepared by diluting the nitrite stock solution with water. A mixing working solution of $0.02 \mathrm{M}$ hydrogen peroxide $\left(\mathrm{H}_{2} \mathrm{O}_{2}\right)$ and $0.1 \mathrm{M} \mathrm{HCl}$ was freshly prepared by volumetric dilution of commercial $30 \%(\mathrm{v} / \mathrm{v}) \mathrm{H}_{2} \mathrm{O}_{2}$ and $36 \%(\mathrm{v} / \mathrm{v})$ $\mathrm{HCl}$ with ultrapure water, respectively (Beijing Chemical Reagent Company). A 0.4 $\mathrm{M} \mathrm{Na}_{2} \mathrm{CO}_{3}$ (pH 11.68) working solution was prepared by dissolving appropriate amounts of $\mathrm{Na}_{2} \mathrm{CO}_{3}$ (Beijing Chemical Factory, Beijing, China) in ultrapure water. Cotton used was commercially absorbent cotton and made of pure cellulose (Beijing Filter Company, Beijing, China).

\subsection{Apparatus and procedures}

A flow system was illustrated in Fig. 1. It consisted of one peristaltic pump (SJ-1211, Atto, Tokyo, Japan), a $150 \mu \mathrm{l}$ loop injector, a CL cell (glass tube: $3.0 \mathrm{~cm}$ in length and $0.3 \mathrm{~cm}$ i.d. packed with a filtering material), and a CL luminometer (Lumiflow LF-800, Microtec Niti-On, Funabashi, Japan). Black Teflon tube (1-mm i.d.) was used for the flow lines. The peak height of the signal recorded was measured as CL intensity. The CL spectrum was obtained using a F-2500 fluorescence spectrophotometer (Hitachi, Tokyo, Japan). A Shimadzu UV-2401 UV-visible recording spectrophotometer (Shimadzu, Kyoto, Japan) was used for comparing with the present $\mathrm{CL}$ method and measuring optical spectra. For pH measurements, an Orion Model $828 \mathrm{pH}$ meter (Massachusetts, USA) was used. A YSI Model 52 dissolved oxygen meter (Ohio, USA) was used for measuring the content of oxygen in aqueous solutions.

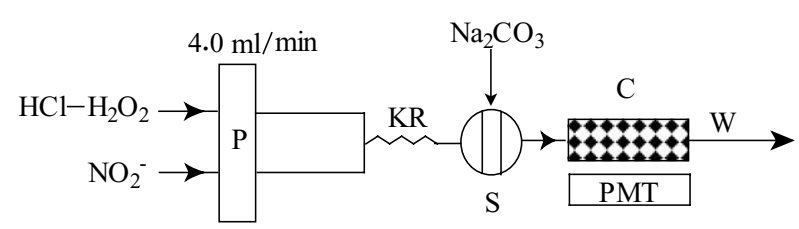

Fig. 1. Schematic diagram of the flow-injection chemiluminescence system. P, peristaltic pump; S, $150 \mu \mathrm{l}$ sample injector; C, CL cell (glass tube: $3.0 \mathrm{~cm}$ in length and $0.3 \mathrm{~cm}$ i.d. packed with $0.03 \mathrm{~g}$ cotton); KR, knotted reactor $(15 \mathrm{~cm})$; W, waste; PMT, photomutiplier tube $(-800 \mathrm{~V})$. The concentrations of $\mathrm{H}_{2} \mathrm{O}_{2}, \mathrm{HCl}$, and $\mathrm{Na}_{2} \mathrm{CO}_{3}$ were $0.02,0.1$, and $0.4 \mathrm{M}$, respectively. 
As shown in Fig. 1, through the injector a $150 \mu l$ of $\mathrm{Na}_{2} \mathrm{CO}_{3}$ was injected into the peroxynitrous acid ( $\mathrm{pH}$ 1.24), which was produced on-line by the reaction between nitrite and acidified hydrogen peroxide. A $15 \mathrm{~cm}$ knotted reactor was used to enhance the mixing of nitrite and $\mathrm{H}_{2} \mathrm{O}_{2} / \mathrm{HCl}$ solution, and then the mixing solution of $\mathrm{Na}_{2} \mathrm{CO}_{3}$ and peroxynitrous acid mixture ( $\mathrm{pH}$ 10.29) passed through the CL cell (packed with $0.03 \mathrm{~g}$ cotton), which was mounted directly in front of the photomultiplier tube of the luminometer, and the CL signals generated from the CL cell were recorded with a Shimadzu U-125 MN recorder (Shimadzu). The stocking time of the tap and well waters should be controlled as short as possible.

For the CL spectrum, $0.02 \mathrm{M} \mathrm{H}_{2} \mathrm{O}_{2}$ in $0.1 \mathrm{M} \mathrm{HCl}, 0.1 \mathrm{M}$ $\mathrm{NO}_{2}{ }^{-}$, and $0.4 \mathrm{M} \mathrm{Na}_{2} \mathrm{CO}_{3}$ solutions were fed through separate lines into a cell placed inside the cell holder of the fluorescence spectrophotometer. The flow rates for $\mathrm{H}_{2} \mathrm{O}_{2} / \mathrm{HCl}$, $\mathrm{NO}_{2}{ }^{-}$, and $\mathrm{Na}_{2} \mathrm{CO}_{3}$ solutions were $4.0,4.0$, and $3.5 \mathrm{ml} / \mathrm{min}$, respectively. The excitation lamp was off and the emission slit width was opened maximally to $20 \mathrm{~nm}$ during the CL spectrum recording.

\section{Results and discussion}

\subsection{CL method}

In our previous work [11], a weak CL signal was produced due to decomposition of peroxynitrite into $\mathrm{NO}^{-}$and ${ }^{1} \mathrm{O}_{2}$ (the proposed CL emitter). The peroxynitrite was generated from peroxynitrous acid in $\mathrm{NaOH}$ solution, and the peroxynitrous acid was produced as a result of the reaction of nitrite with acidified hydrogen peroxide. In the present work, both the replacement of $\mathrm{NaOH}$ by $\mathrm{Na}_{2} \mathrm{CO}_{3}$ and the addition of solid material were found to enhance the CL emission generated from the nitrite-hydrogen peroxide reaction. Table 1 showed the effects on the relative CL intensity as a function of the presence of $\mathrm{NaOH}, \mathrm{Na}_{2} \mathrm{CO}_{3}$, and solid material (cotton). Experiment 1 indicated that in the presence of $\mathrm{NaOH}$, a relatively weak $\mathrm{CL}$ intensity was observed. As described in our previous work [11], ${ }^{1} \mathrm{O}_{2}$ is the light emitting species. On the other hand, the replacement of $\mathrm{NaOH}$

Table 1

Relative CL intensity of $\mathrm{H}_{2} \mathrm{O}_{2} / \mathrm{HCl} / \mathrm{NO}_{2}{ }^{-}$system under different CL systems

\begin{tabular}{llc}
\hline Experiments & $\mathrm{CL}$ system & Relative CL intensity \\
\hline 1 & $\mathrm{NaOH}$ & $0.01 \pm 0.003$ \\
2 & $\mathrm{Na}_{2} \mathrm{CO}_{3}$ & $10 \pm 0.7$ \\
3 & $\mathrm{Na}_{2} \mathrm{CO}_{3}+$ cotton & $700 \pm 8.5$ \\
\hline
\end{tabular}

a The concentrations of $\mathrm{H}_{2} \mathrm{O}_{2}, \mathrm{HCl}, \mathrm{NO}_{2}{ }^{-}, \mathrm{NaOH}$, and $\mathrm{Na}_{2} \mathrm{CO}_{3}$ were $0.02,0.1,0.1,0.15$, and $0.4 \mathrm{M}$, respectively. The mass of cotton is $0.03 \mathrm{~g}$ cotton. The flow-injection method was used. The flow rates of $\mathrm{H}_{2} \mathrm{O}_{2} / \mathrm{HCl}$ and $\mathrm{NO}_{2}{ }^{-}$solution were $4.0 \mathrm{ml} / \mathrm{min}$. The $\mathrm{Na}_{2} \mathrm{CO}_{3}$ solution flow rate was $3.5 \mathrm{ml} / \mathrm{min}$.

b Each CL intensity represented the mean of five measurements \pm S.D.
Table 2

Effect of solid material on the relative intensity ${ }^{\mathrm{a}}$

\begin{tabular}{llc}
\hline Solid material $^{\mathrm{b}}$ & Dry weight $(\mathrm{mg})$ & Relative CL intensity $^{\mathrm{c}}$ \\
\hline None & & $10 \pm 0.8$ \\
Cotton & 30 & $700 \pm 5.2$ \\
Filter paper & 35 & $360 \pm 2.6$ \\
Glass wool & 28 & $220 \pm 3.3$ \\
Polyvinylchloride & 64 & $80 \pm 2.1$ \\
Foam plastic & 26 & $50 \pm 1.6$ \\
\hline
\end{tabular}

a All conditions were the same as in Table 1.

${ }^{b}$ Normalized with respect to the signal in the absence of solid material.

${ }^{c}$ Each CL intensity represented the mean of five measurements \pm S.D.

by $\mathrm{Na}_{2} \mathrm{CO}_{3}$ (Experiment 2) resulted in a significant increase in the CL intensity. When compared Experiments 2 and 3, the presence of cotton provided a dramatic enhancement on the CL intensity.

\subsection{Solid material}

As shown in Table 2, five different solid materials were compared and results showed that all the solid materials used can enhance the CL signal and the CL intensity was increased with the increasing of mass of each solid material. We thought that this phenomenon might be attributed to more sufficient mixing of reaction reagent solutions on solid surface, resulting in an increase in the CL efficiency and/or rate of reaction [12]. However, when the mass of each solid material examined was optimum, cotton provided the highest CL intensity, giving a 70-fold enhanced CL signal. This is due to the fact that oxygen, absorbed in the charge-transfer interactions in cotton, is easily converted to oxygen anion radical $\left(\mathrm{O}_{2}{ }^{\bullet-}\right)$ at room temperature [18-20], and the reaction of $\mathrm{O}_{2}{ }^{\bullet-}$ radical with bicarbonate leads to the generation of $\mathrm{HCO}_{3} \bullet$ radical [21-23], which is attributed to the proposed CL emitter in this study. In our experiment, an optimal amount of cotton of $0.03 \mathrm{~g}$ was chosen on account of larger amounts of cotton leading to blockage of FIA channels.

\subsection{Optimal conditions for the FIA-CL system}

To establish the optimal conditions for the flow-injection analysis of nitrite, the ratio of the peak height of CL signal to noise $(S / N)$ was measured as a function of the concentrations of $\mathrm{HCl}, \mathrm{Na}_{2} \mathrm{CO}_{3}$, and $\mathrm{H}_{2} \mathrm{O}_{2}$.

The formation of peroxynitrous acid from the reaction of nitrite and hydrogen peroxide needs the presence of acid as catalyst. Based on our previous work [11], a concentration of $0.1 \mathrm{M} \mathrm{HCl}$ was chosen in further experiments.

The CL intensity was strongly dependent on the concentration of $\mathrm{Na}_{2} \mathrm{CO}_{3}$. In the absence of $\mathrm{Na}_{2} \mathrm{CO}_{3}$, no CL signal was obtained with our CL apparatus. A concentration of $0.4 \mathrm{M} \mathrm{Na}_{2} \mathrm{CO}_{3}$ was operated as one of FIA-CL optimum conditions.

The effect of the concentration of hydrogen peroxide on the CL intensity was investigated in the range of $0.001-0.1 \mathrm{M}$ 
Table 3

Analytical characteristics of nitrite determination

\begin{tabular}{ll}
\hline Concentration $\left(10^{-6} \mathrm{M}\right)$ & Relative CL intensity ${ }^{\mathrm{a}}$ \\
\hline 0 (blank) & 0 \\
0.2 & $0.31 \pm 0.02$ \\
0.4 & $0.51 \pm 0.01$ \\
0.8 & $0.95 \pm 0.04$ \\
1.0 & $1.15 \pm 0.18$ \\
2.0 & $2.63 \pm 0.21$ \\
4.0 & $5.02 \pm 0.34$ \\
6.0 & $7.66 \pm 0.28$ \\
8.0 & $9.91 \pm 0.32$ \\
Calibration curve & $I_{\mathrm{CL}}=0.015+1.25 \times 10^{6}\left[\mathrm{NO}_{2}{ }^{-}\right]$ \\
Correlation coefficient & $r=0.9996$ \\
Dynamic linear range & $2.0 \times 10^{-7}-8.0 \times 10^{-5} \mathrm{M}^{-7} \mathrm{M}$ \\
Detection limit $(S / N=3)$ & $1.0 \times 10^{-7} \mathrm{M}=$ \\
\hline
\end{tabular}

${ }^{a}$ Each CL intensity represented the mean of three measurements \pm S.D.

$\mathrm{H}_{2} \mathrm{O}_{2}$. The result showed that the optimal concentration of hydrogen peroxide was $0.02 \mathrm{M} \mathrm{H}_{2} \mathrm{O}_{2}$.

\subsection{Determinations of nitrite in tap and well waters}

On the basis of the above experiments, the analytical figures of merit of the present method were listed in Table 3 and we found that there was a good linear relationship between the nitrite concentration and the CL intensity. The average precision of the overall analysis was $4.6 \%(n=7)$ and the detection limit $(S / N=3)$ was $1.0 \times 10^{-7} \mathrm{M}$ nitrite, which should be sufficient for the measurement of trace nitrite in tap and well waters. The relative standard deviation (R.S.D.) for batch-to-batch results was $5.8 \%$. The effect of various interferences concurrently presented in water was also studied. The results showed that most of the ions such as 1000 -fold $\mathrm{Ca}^{2+}, \mathrm{Br}^{-}, \mathrm{F}^{-}, \mathrm{Cl}^{-}, \mathrm{NH}_{4}{ }^{+}, \mathrm{SO}_{4}{ }^{2-}, \mathrm{NO}_{3}{ }^{-}$, $\mathrm{Pb}^{2+}$, and 500-fold $\mathrm{SiO}_{3}{ }^{2-}, \mathrm{H}_{2} \mathrm{PO}_{4}^{-}, \mathrm{HPO}_{4}{ }^{2-}, \mathrm{Cd}^{2+}$, $\mathrm{Mg}^{2+}, \mathrm{Al}^{3+}, \mathrm{Ni}^{2+}, \mathrm{OCl}^{-}$, and 200-fold $\mathrm{Cu}^{2+}, \mathrm{Zn}^{2+}, \mathrm{Fe}^{2+}$, $\mathrm{Mn}^{2+}, \mathrm{Fe}^{3+}, \mathrm{Hg}^{2+}, \mathrm{Cr}(\mathrm{VI})$, and 100-fold $\mathrm{Co}^{2+}$ and $\mathrm{Cr}^{3+}$ have no influence on the determination of $1.0 \times 10^{-6} \mathrm{M}$ nitrite. These results were not surprising since ${ }^{\bullet} \mathrm{NO}_{2}$ and ${ }^{-} \mathrm{CO}_{3}{ }^{-}$radicals as a result of the reaction between peroxynitrite and $\mathrm{CO}_{2}$ are in the same solvent cage and these radical pairs may not escape from the solvent cage to any significant extent [24-26]. In the case an extremely rapid radical-radical combination must take place in the solvent cage to generate nitrite and nitrate (Reactions 7 and 8) or give light emission (Reaction 10).

Table 4 showed the nitrite contents of the five different natural water samples. Well water comes from deep-groundwater, which is relatively clean and can be drunk directly without pretreatment. Freshly collected samples were filtered through a membrane filter of $0.45 \mu \mathrm{m}$ pore size to remove any suspended solids, kept in a refrigerator at about $4{ }^{\circ} \mathrm{C}$ and analyzed by the recommended procedure within $12 \mathrm{~h}$ of collection. The analytical results of the present method were evaluated by comparing the contents of nitrite in tap and well waters obtained between the present CL and a standard spectrophotometric method [17]. As shown in Table 4, the results obtained with the two methods were in good agreements for the determination of nitrite in tap and well waters.

\subsection{Possible mechanism of the present CL system}

The present work indicated that there was no CL observed from the reaction of nitrite with acidified hydrogen peroxide without carbonate, and then the effect of carbonate on the CL signal was very evident. It was well known that a number of CL analyses were carried out in the presence of carbonate solution not only based on its buffer function but also the CL enhancement [27-29]. To clarify the CL mechanism of the present system, the following experiments were carried out.

\subsubsection{Effect on $\mathrm{O}_{2}$ in solution}

To investigate directly the effect of and $\mathrm{O}_{2}$ on CL, all solutions were prepared with fresh ultrapure water and these solutions were degassed with bubbling $\mathrm{N}_{2}$ gas for $10 \mathrm{~min}$. When $\mathrm{Na}_{2} \mathrm{CO}_{3}$ solution was bubbled with $\mathrm{O}_{2}$ for $10 \mathrm{~min}$, the CL intensity stayed relatively constant, indicating that $\mathrm{O}_{2}$ played no role in the $\mathrm{CL}$ reaction. However, under our optimum CL conditions, nitrite solution, $\mathrm{H}_{2} \mathrm{O}_{2} / \mathrm{HCl}$ solution and carbonate solution were pumped through the continuous flow system and mixed in a coiled flow cell. The $\mathrm{O}_{2}$ content in the flow cell was measured with dissolved oxygen meter $\left(\mathrm{O}_{2}\right.$-sensing polarographic electrode). The results showed that the $\mathrm{O}_{2}$ content increased by $2.5 \mathrm{mg} / 1$, indicating the production of $\mathrm{O}_{2}$ from the reaction of peroxynitrous

Table 4

Standard parameters and nitrite determination in natural water samples

\begin{tabular}{|c|c|c|c|c|c|}
\hline Sample ${ }^{a}$ & $\mathrm{pH}$ & Hardness $\left(\mathrm{mg} / 1 \mathrm{CaCO}_{3}\right)$ & Conductivity (mS/m) & Present method ${ }^{\mathrm{b}}\left(10^{-6} \mathrm{M}\right)$ & Spectrophotometric method $\left(10^{-6} \mathrm{M}\right)$ \\
\hline A & 7.28 & 65 & 36 & $0.63 \pm 0.02$ & $0.58 \pm 0.03$ \\
\hline B & 7.16 & 72 & 48 & $0.57 \pm 0.03$ & $0.61 \pm 0.02$ \\
\hline $\mathrm{C}$ & 7.35 & 69 & 54 & $0.61 \pm 0.04$ & $0.65 \pm 0.04$ \\
\hline $\mathrm{D}$ & 7.27 & 76 & 69 & $0.35 \pm 0.03$ & $0.40 \pm 0.04$ \\
\hline $\mathrm{E}$ & 7.19 & 70 & 57 & $0.43 \pm 0.02$ & $0.39 \pm 0.03$ \\
\hline
\end{tabular}

a Samples A-C were tap water obtained from three different districts of Beijing. (A) Haidian district, (B) Chongwen district, (C) Xuanwu district. Samples D-E were well water obtained from two different districts of Beijing. (D) Haidian district, (E) Chaoyang district.

b All the results are the mean of three determinations \pm S.D. 
acid with carbonate solution, which was consistent with the published paper [30].

\subsubsection{CL spectrum}

There are many reports of the decomposition of the peroxynitrite to form ${ }^{1} \mathrm{O}_{2}$ [31,32], which is the light emitting species. It is known that there are several maxima in the emission spectra of ${ }^{1} \mathrm{O}_{2}$, i.e. $1269,762,634,476$, and $381 \mathrm{~nm}$ $[33,34]$. Also, when no cotton was packed in the CL cell, 1,4-diazabicyclo [2,2,2,2,]octane (DABCO) and $\mathrm{NaN}_{3}$ [35], well-known quenchers of ${ }^{1} \mathrm{O}_{2}$, were used in the present experiment. The results showed DABCO and $\mathrm{NaN}_{3}$ did not quench the $\mathrm{CL}$ intensity, which provided strong evidence that ${ }^{1} \mathrm{O}_{2}$ did not contribute to the observed CL. A number of investigations $[25,26,30,36]$ have demonstrated that that peroxynitrite can react with bicarbonate/carbon dioxide to form an adduct, $\mathrm{ONOOCO}_{2}{ }^{-}$, which can decompose into ${ }^{\bullet} \mathrm{CO}_{3}{ }^{-}$radicals. Radi et al. [15] observed the reaction from peroxynitrite with bicarbonate could lead to an increase of luminol CL by the formation of $\mathrm{ONOOCO}_{2}^{-}$. Furthermore, formation of $\mathrm{HCO}_{3} \bullet$ radicals during peroxynitrite decay in alkaline carbonate buffers had also been suggested [8]. In the present study, the CL spectrum of peroxynitrous acid in carbonate solution showed that there was only a peak band in the range of $416-460 \mathrm{~nm}$, which resulted from the reaction $\mathrm{HCO}_{3} \bullet$ radicals $[21,23]$ and these results are in good agreement with the previous studies $[8,15]$.

\subsubsection{UV spectrum}

The UV absorption of peroxynitrous acid from the reaction of nitrite and $\mathrm{H}_{2} \mathrm{O}_{2} / \mathrm{HCl}$ was given in Fig. 2. The absorption peak at $301 \mathrm{~nm}$ was due to the formation of nitrate by the isomerization of peroxynitrous acid (solid line). However, after rapid mixing of HOONO with carbonate solution (dashed line), a new band appeared at $354 \mathrm{~nm}$ resulted from the decomposition of $\mathrm{ONOOCO}_{2}{ }^{-}$to nitrite, whereas the characteristic band of nitrate at $301 \mathrm{~nm}$ did not disappear. This suggested that nitrate $[8,9]$ is the only product in the spontaneous decomposition of peroxynitrous acid (solid line) and both nitrite and nitrate [6,30] were formed simultaneously in the reaction from peroxynitrous acid with carbonate solution (dashed line).

Based on the above results, the CL mechanism can be summarized as the follow reactions: HOONO was formed through the reaction of nitrite with acidified $\mathrm{H}_{2} \mathrm{O}_{2}$ (Reaction 1). HOONO is an unstable compound in acidic solution and can be converted into $\mathrm{ONOO}^{-}$in basic solution as a function of the protonation of $\mathrm{CO}_{3}{ }^{2-}$ to $\mathrm{HCO}_{3}{ }^{-}$(Reactions 2 and 3 ).

$$
\begin{aligned}
& \mathrm{H}_{2} \mathrm{O}_{2}+\mathrm{HNO}_{2} \rightarrow \mathrm{HOONO}+\mathrm{H}_{2} \mathrm{O} \\
& \mathrm{ONOOH}+\mathrm{OH}^{-} \rightarrow \mathrm{ONOO}^{-}+\mathrm{H}_{2} \mathrm{O} \\
& \mathrm{CO}_{3}{ }^{2-}+\mathrm{H}_{2} \mathrm{O} \rightleftharpoons \mathrm{HCO}_{3}^{-}+\mathrm{OH}^{-}
\end{aligned}
$$

High levels of bicarbonate can protonate to carbonic acid $\left(\mathrm{H}_{2} \mathrm{CO}_{3}\right)$, which is in equilibrium with aqueous $\mathrm{CO}_{2}[8,36]$ (Reaction 4).

$\mathrm{HCO}_{3}{ }^{-}+\mathrm{H}^{+} \rightleftharpoons \mathrm{H}_{2} \mathrm{CO}_{3} \rightleftharpoons \mathrm{CO}_{2}(\mathrm{aq})+\mathrm{H}_{2} \mathrm{O}$

The rapid reaction of peroxynitrite with $\mathrm{CO}_{2}$ results in the formation of an adduct $\mathrm{ONOOCO}_{2}{ }^{-}[25,26,30,36](\mathrm{Re}-$ action 5).

$\mathrm{ONOO}^{-}+\mathrm{CO}_{2} \rightarrow \mathrm{ONOOCO}_{2}^{-}$

It has been proposed $[26,30,36]$ that $\mathrm{ONOOCO}_{2}{ }^{-}$has a lifetime shorter than $3 \mathrm{~ms}$ and can rapidly decompose into $\bullet \mathrm{NO}_{2}$ and ${ }^{\bullet} \mathrm{CO}_{3}{ }^{-}$radical pair at the weak peroxo $\mathrm{O}-\mathrm{O}$ bond.

$\mathrm{ONOOCO}_{2}^{-} \rightarrow{ }^{\bullet} \mathrm{NO}_{2}+{ }^{\bullet} \mathrm{CO}_{3}^{-}$

As spectrophotometrically experimental data were shown in Fig. 2. The recombination between ${ }^{\bullet} \mathrm{NO}_{2}$ and ${ }^{\bullet} \mathrm{CO}_{3}{ }^{-}$radicals generates nitrite and nitrate in aqueous solution $[6,30]$ (Reactions 7 and 8).

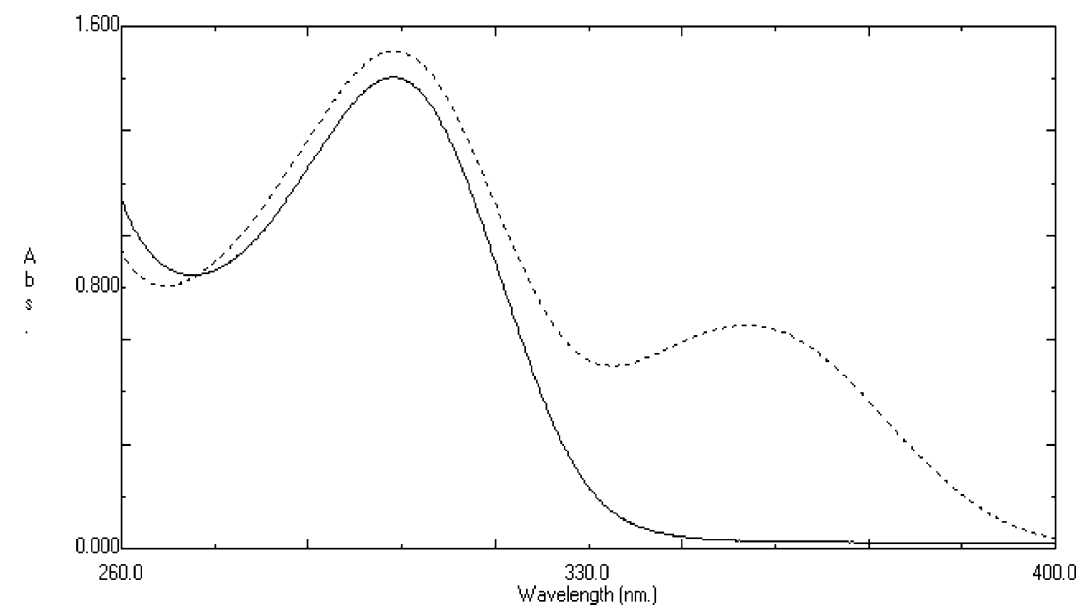

Fig. 2. Absorption spectra of peroxynitrous acid from the reaction of nitrite and $\mathrm{H}_{2} \mathrm{O}_{2} / \mathrm{HCl}$ in the absence (solid line) and presence (dashed line) $\mathrm{Na} \mathrm{CO}_{3}$ solution. The concentrations of $\mathrm{NO}_{2}{ }^{-}, \mathrm{H}_{2} \mathrm{O}_{2}, \mathrm{HCl}$, and $\mathrm{Na}_{2} \mathrm{CO}_{3}$ were $0.6,0.7,0.6$, and $1.0 \mathrm{M}$, respectively. The volume of each solution was 1.0 ml. 
$\cdot \mathrm{NO}_{2}+{ }^{\bullet} \mathrm{NO}_{2}+\mathrm{H}_{2} \mathrm{O} \rightarrow \mathrm{NO}_{2}{ }^{-}+\mathrm{NO}_{3}{ }^{-}+2 \mathrm{H}^{+}$

$\cdot \mathrm{NO}_{2}+{ }^{\bullet} \mathrm{CO}_{3}{ }^{-} \rightarrow \mathrm{NO}_{3}{ }^{-}+\mathrm{CO}_{2}$

In the presence of $\mathrm{H}^{+},{ }^{\bullet} \mathrm{CO}_{3}{ }^{-}$radical can protonate to $\mathrm{HCO}_{3}{ }^{\bullet}$ radical [22,37] (Reaction 9).

$\cdot \mathrm{CO}_{3}{ }^{-}+\mathrm{H}^{+} \rightleftharpoons \mathrm{HCO}_{3}{ }^{\bullet}$

The recombination of $\mathrm{HCO}_{3}{ }^{\bullet}$ radical and decomposition could generate $\mathrm{CL}$ and the emission band is approximately at $400-460 \mathrm{~nm}$, which fitted with the experimental CL spectrum and was reported by many investigations $[8,21,23]$ (Reaction 10).

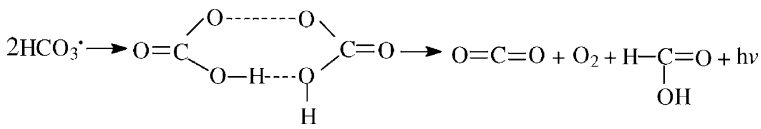

\section{Conclusion}

In this study, based on the CL spectrum, UV spectra, and dissolved oxygen measurement, a reasonable CL mechanism from the reaction of $\mathrm{ONOOH}$ with carbonate was proposed. Furthermore, the possible mechanism of the solid surface enhancement on $C L$ was discussed in brief. The feasibility of employing the present CL system in the presence of cotton for the sensitive and selective determination of nitrite in tap and well waters was demonstrated. The present method has been shown to exhibit higher tolerance towards a large number of matrix interference ions in natural water samples.

\section{Acknowledgements}

Financial support from National Science Fund for Distinguished Young Scholars of China (No. 20125514) and from National High Technology Research and Development Program of China (863 Program) (No. 2001AA635030) is gratefully acknowledged.

\section{References}

[1] H.P.S. Rathore, S.K. Tiwari, Anal. Chim. Acta 242 (1991) 225.

[2] J.H. Pei, X.Y. Li, Talanta 51 (2000) 1107.
[3] D.W. Bedwell, V.R. Rivera, G.A. Merrill, A.E. Pusaterr, Anal. Biochem. 284 (2000) 1.

[4] R.D. Cox, Anal. Chem. 52 (1980) 332.

[5] A.R. Thornton, J. Pfab, R.C. Massey, Analyst 114 (1989) 747.

[6] S.V. Lymar, Q. Jiang, J.K. Hurst, Biochemistry 35 (1996) 7855

[7] L. Zhu, C. Gunn, J.S. Beckman, Arch. Biochem. Biophys. 298 (1992) 452.

[8] A. Denicola, B.A. Freeman, M. Trujillo, R. Radi, Arch. Biochem. Biophys. 333 (1996) 49.

[9] A. Saha, S. Goldstein, D. Cabelli, G. Czapski, Free Radical Biol. Med. 24 (1998) 653.

[10] P. Mikuska, Z. Vecera, Z. Zdrahal, Anal. Chim. Acta 316 (1995) 261.

[11] C. Lu, F. Qu, J.-M. Lin, M. Yamada, Anal. Chim. Acta 474 (2002) 107.

[12] T. Yoshinaga, Y. Tanaka, T. Ichimura, H. Hiratsuka, M. Kobayashi, T. Hoshi, J. Lumin. 78 (1998) 221.

[13] E.S. Rich, H. Clark, G.J.E. Wampler, Photochem. Photobiol. 33 (1981) 727.

[14] J.R. Lu, X.R. Zhang, W.Z. Fan, Z.J. Zhang, Anal. Chim. Acta 262 (1992) 225.

[15] R. Radi, T.P. Cosgrove, J.S. Beckman, B.A. Freeman, Biochem. J. 290 (1993) 51.

[16] K. Dai, A.G. Vlessidis, N.P. Evmiridis, Talanta 59 (2003) 55.

[17] F.S. Wei, Analytical Methods for the Examination of Water and Wastewater, third ed., Chinese Environment and Science Press, Beijing, 1998, $260 \mathrm{pp}$.

[18] W. Adam, Chem. Z. 99 (1975) 142.

[19] M. Strlic, J. Kolar, B. Pihlar, J. Rychly, L. Matisova-Rychla, Polym. Degrad. Stab. 72 (2001) 157.

[20] L. Matisova-Rychla, J. Rychly, G.A. George, Polym. Degrad. Stab. 75 (2002) 385.

[21] J. Wierzchowski, D. Slawinska, J. Slawinski, Z. Phys. Chem. Neue Folge 148 (1986) 197.

[22] J. Stauff, U. Bergmann, Z. Phys. Chem. Neue Folge 78 (1972) 263.

[23] J.-M. Lin, M. Yamada, Anal. Chem. 71 (1999) 1760.

[24] G.R. Hodges, K.U. Ingold, J. Am. Chem. Soc. 121 (1999) 10695.

[25] H.W. Zhang, G.L. Squadrito, R.M. Uppu, J.-N. Lemercier, R. Cueto, W.A. Pryor, Arch. Biochem. Biophys. 339 (1997) 183.

[26] R.M. Uppu, G.L. Squadrito, W.A. Pryor, Arch. Biochem. Biophys. 327 (1996) 335.

[27] J.-M. Lin, T. Hobo, Anal. Chim. Acta 323 (1996) 69.

[28] N. Duran, H. Mansila, L.C.C. Leite, A. Faljoni, J. Inorg. Biochem. 34 (1988) 105.

[29] D. Stawinska, J. Stawinski, J. Biolumin. Chemilumin. 13 (1998) 13.

[30] S.V. Lymar, J.K. Hurst, Inorg. Chem. 37 (1998) 294.

[31] P. Di Mascio, E.J.H. Bechara, M.H.G. Mediros, K. Briviba, H. Sies, FEBS Lett. 355 (1994) 287.

[32] A.U. Khan, D. Kovacic, A. Kolbanovskiy, M. Desai, K. Frenkel, N.E. Geacintov, Proc. Natl. Acad. Soc. USA 97 (2000) 2984.

[33] X.-Z. Wu, M. Yamada, T. Hobo, S. Suzuki, Anal. Chem. 61 (1989) 1505.

[34] H.H. Wasserman, R.W. Murray, Singlet Oxygen, Academic Press, New York, 1979, 24 pp.

[35] J.-M. Lin, M. Yamada, Anal. Chem. 72 (2000) 1148.

[36] S. Goldstein, G. Czapski, J. Am. Chem. Soc. 120 (1998) 3458.

[37] S. Chen, M.Z. Hoffman, Radiat. Res. 56 (1973) 40. 